\title{
DIE AKTUALITEIT VAN NICEA
}

\author{
DR. D. J. SMITH
}

\section{A. DIE VRAAG NA DIE AKTUALITEIT VAN 'N BELYDENIS}

Aangesien nog twee referente oor dieselfde belydenis handel, was daar die besliste moontlikheid van herhaling. In die lig hiervan is die vryheid geneem om die aktualiteit van Nicea so in behandeling te neem dat dit nie net draai om die een saak waarom dit by Nicea gegaan het nie, In. die christologiese stryd met die Ariane nie, maar om die hele veld van belydenisartikels wat deur die belydenis in sy huidige vorm omvat word, te neem en dit as aanloop te gebruik om sekere tendense in die nuwere strominge in die teologie te skets en dan die aktualiteit van Nicea hieraan te meet.

Daar kan nie oor die aktualiteit van Nicea gepraat word nie sonder om ook die vraag te vra na wat 'n geloofsbelydenis wesenlik is nie, want juis dit wat ' $n$ belydenis is en wil wees, maak dit aktueel vir elke nuwe geslag wat dit bely. In die loop van die kerkgeskiedenis het daar in hoofsaak vier opvattings na vore gekom van wat 'n belydenisskrif van die kerk wesenlik is. ${ }^{1}$ ) Die eerste opvatting waarop ons wil wys, is die opvatting dat die belydenis uitgespreek deur die kerk 'n onfeilbare dekreet of besluit sou wees. Dit is die standpunt van Rome en is gebou op die twee spreuke: „Roma locuta, causa finita" (As Rome gespreek het, is die saak besleg) en "Roma semper eadem" (Rome is altyd dieselfde). Hiernaas staan die standpunt wat veral onder die dweper Wederdopergroepe sedert die sestiende eeu na vore gekom het. Dit is. naamlik die opvatting dat die geskrewe belydenis niks anders is as ' $n$ ysterband, 'n ketting wat die gewete ongenadiglik bınd. Die belydenis is iets wat verwerp moet word omdat dit die vryheid van die gelowige, die vryheid van die werking van die Heilige Gees en die waardigheid en gesag van die Heilige Skrif sou aantas. ' $n$ Derde mening is dat die geskrewe belydenis van die kerk wel aanvaar moet word as ' $n$ wegwyser, 'n baken vir die geloof, maar dan slegs as ' $n$ voorlopige wegwyser sonder bindend gesag in kerkregtelike sin. Dit was onder andere die standpunt van die Remonstrante van die sestiende eeu. Die laaste opvatting waarop ons wil wys is die opvatting van die groot manne van die Kerkhervorming. Die belydenis van die kerk is ' $n$ herhaling van die Woord van God en daarom dan ook 'n vaste maatstaf vir die geloof. Die belydenis het ' $n$ gesag wat op Gods Woord self, waaruit dit voortkom, rus omdat dit ooreenkomstig en gelykvorming aan Gods Woord opgestel is.

1) A. D. R. Polman gee 'n baie deeglike en waardevolle oorsig van die sieninge in sy werk: Onze Nederlandsche Geloofsbelydenis, verklaard uit het verleden, gekonfronteerd met het heden, deel I, Franeker z.j., blz. 9 v.v. 
Hierdie laaste standpunt gee die ware wese van die belydenis weer. Dit is dan ook die eerste opsig waarin die belydenis van Nicea aktueel is vir ons dag. In 'n tyd waarin God se Woord al hoe meer tot swye gebring word en waarin die gesag van die Woord afgetakel word, wil die Nicenum as ' $n$ belydenis van die kerk die groot waarhede van die Skrif openlik voor die ganse wêreld herhaal. Dit wil die gesag van die Woord waaruit dit gegroei het belydend handhaaf.

Voordat ons in besondere ingaan op die waarde van Nicea vir ons dag, wil ons ook eers wys op die noodsaaklikheid van die belydenis van die kerk. ${ }^{2}$ ) Die eerste rede vir die vorming van 'n belydenis lê in die bestaan van die kerk self. Die belydenis is iets wat vanself uit die kerk na vore moet kom, want die kerk kan nie anders as om die geloof waaruit hy lewe openlik uit te spreek nie. Die kerk moet die Waarheid waaruit hy leef, duidelik vas lê. Dit is 'n lewensnoodsaaklikheid dat die kerk sy geloof in skerp begrensde begrippe sal saamvat want onsekere en swewende begrippe lei alleen tot twyfel en aftakeling van die kerk self. Nicea voldoen vandag nog steeds in uitnemende mate aan hierdie lewensnoodsaaklike behoefte van die kerk om sy geloof in helder omlynde begrippe saam te vat. Veral gesien in die lig van die groot beweging dwarsooor die wêreld om die grense en omlyninge van die geloof so vaag moontlik te hou sodat daar een groot wêreldkerk tot stand kan kom wat nie op die Waarheid in Christus gebou is nie, maar uit en uit alleen op ' $n$ organisatoriese eenheid, kan Nicea nie duidelik genoeg gehoor word nie.

'n Verdere rede vir die vorming en handhawing van ' $n$ belydenis lê in die noodsaak van selfverdediging en die handhawing van die suiwerheid van die leer. In die geskiedenis van die ontstaan van die belydenisse van die kerk is dit baie duidelik dat een van die groot aanleidings daartoe die bedreiging van die kerk deur die opkoms van dwalinge en valse leer was. Die valse leer vorm ' $n$ bedreiging vir die kerk as die ware liggaam van Jesus Christus. Daarom moet die kerk hom ter wille van sy eie voortbestaan afgrens teen die ketters, en dit doen hy in sy belydenis. Uit ons verdere betoog sal dit blyk hoe die bestaan van die kerk self in ons dag bedreig word deur dwaalleer en kettery. Die kerk as liggaam van Christus is op die spel en vir die verdediging van sy bestaan en die handhaaf van die suiwere leer, het die kerk ' $n$ uitnemende wapen in die kort maar kragtige belydenis van Nicea.

Deur sy belydenis betuig die kerk ook sy eenheid in die Waarheid, sy eenheid in die Woord, in Christus. Deur die belydenis van Nicea kan ons ook vandag aan die wêreld betuig dat ons eenheid

2) A. D. R. Polman gee 'n baie deeglike behandeling van die noodsaaklikheid van belydenisskrifte in sy aangehaalde werk blz. 52 v.v. 
alleen in die Waarheid lê, die Waarheid soos beliggaam in die Woord van God wat vlees geword het, Jesus Christus.

Die aktualiteit van 'n belydenis soos die van Nicea staan dus vas, maar nou bly die vraag: watter strominge in die wêreld, watter bedreiginge in die kerk, watter afdwalinge van Gods Woord en die leer van die kerk, roep hierdie aktualiteit van die belydenis in ons dag na vore? Hierop wil ons in die volgende afdeling uitbrei.

\section{B. NICEA TEENOOR DIE NUWERE STROMINGE IN DIE TEOLOGIE}

Die huidige opset van die protestantse teologie het 'n besliste sterk neiging wat die handhawing van die belydenis dringend noodsaaklik maak. By 'n noukeurige studie van die nuwere strominge in die teologie word een groot tendens wat in twee fasette uiteenval, duidelik. Hierdie tendens word baie raak beskryf deur Kuitert as die anti-metafisiese tendens in die Teologie. ${ }^{3}$ ) Die anti-metafisiese tendens het twee fasette wat hand aan hand loop. Die eerste groot kenmerk van die teologie is dat dit afskeid wil neem van enige hoëre Goddelike werklikheid. Dit is 'n teologie waarin daar nie meer plek is vir God en sy wêreld nie. Alles wat met die tradisionele God van die Bybel en sy wêreld te doen het, moet uit die teologie gegooi word. Daar is geen plek vir die metafisiese, dit wil sê, dit wat bo die natuurlike, bo die aardse uitgaan nie.

Hand aan hand hiermee gaan die volgende aspek. Namate God uitgeskuif word uit die teologie vind ons ' $n$ vermensliking van die teologie - tot so 'n mate dat ons dit selfs 'n matelose humanisering kan noem. Die teologie het sy blik van die hemel na die aarde verskuif. In die Nuwe teologie is teologie nie meer in die eerste plek spreke van God nie, maar spreke oor die mens en sy wêreld. Die teologie draai om die mens en al sy stoflik-aardse verhoudinge.

Die twee fasette hang ten nouste saam. Die een vloei uit die ander voort. Die vermensliking van die teologie is maar alleen die logiese uitvloeisel van die afskeid in die teologie van God en sy hoëre werklikheid. Hierdie anti-metafisiese tendens in die teologie van ons dag omvat dan ook die hele veld van die teologie. Geen belydenisartikel van die kerk het daardeur onaangeraak gebly nie. Ons wil dan nou vervolgens kortliks en sketsmatig aanstip hoe dat die vernaamste artikels van die algemeen-christelike geloof deur die tendens geraak word om daarteenoor dan die belydenis van Nicea te stel.

3) H. M. Kuitert, De realiteit van het geloof. Over de anti-metafysische tendens in de huidige theologische ontwikkeling, Kampen 19683. . 
Die grootste deel van die Nuwe Teologie se uitsprake oor God, kan gekenmerk word as 'n stryd teen die voorstelling van God as ' $n$ Persoon wat in die hemel woon en die aarde van daar regeer. Die Nuwe Teologie wil niks weet van die voorstelling van God soos ons dit in Sondag 10 van die Heidelbergse Kategismus vind nie, naamlik die God wat vanuit die hemel die aarde so regeer dat „rykdom en armoede en alle dinge nie by toeval nie, maar uit sy vaderlike hand ons toekoms"..") As een van die voorlopers van die Nuwe Teologie is dit veral Rudolf Bultman se uitspraak dat die ou wêreldbeeld van 'n God wat vanuit die hemel regeer, niks anders is as ' $n$ mitologiese voorstelling waarvan die moderne mens afskeid geneem het en moet afskeid neem, ${ }^{5}$ ) wat die groot wedywering in die Nuwe Teologie aan die gang gesit het om God en sy werklikheid uit hierdie wêreld van die mense te ban. Dietrich Bonhoeffer het hierdie neiging nuwe vaart gegee deur te stel dat die moderne mens mondig geword het, dus ryp geword het om sonder God te leef en dat ons ' $n$ toestand bereik het waar ons sonder God in die wêreld moet klaarkom en daarom ook ' $n$ evangelie met ' $n$ nie religieuse verklaring van die Bybel aan die moderne mens moet verkondig, ${ }^{6}$ ) dit wil sê 'n evangelie sonder God. Coxi) dink aan die moontlikheid om die saak nog verder te voer, want wanneer hy oor die woord God praat dan stel hy dat dit nog te vroeg is om dit met sekerheid te kan sê, maar dat dit heel moontlik is dat ons woord God sal moet verdwyn want dit sou tot 'n sekere mate 'n bevestiging wees van die apokaliptiese stelling van Nietzsche dat God dood is. Die uiterste konsekwensie van die teologiese ontwikkeling is getrek in die sogenaamde „God is dood"-teologie wat onbeskaamd van c'ie standpunt uitgaan dat God geen bestaan meer het in ons mensewêreld nie. ${ }^{8}$ ) So is die gang dan voltooi: God as Persoon en sy werking en werklikheid is hier heeltemal uit die aardse werklikheid en mensewêreld geskrap. Al wat oorbly is die mens in sy mondigheid, die mens wat self sy lot bepaal en heil uitwerk, die mens wat die laaste sê het oor hierdie wêreld.

4) J. Sperna 'Weiland, Oriëntatie. Nieuwe wegen in de theologie, Baarn 19672, blz. $148 v$.

5) Hierdie uitspraak van Bultmann vind ons breedvoerig uiteengesit in sy boek: Jesus Christus und die Mythologie. Das Neue Testament im Licht der Bibelkritik, Hamburg 1964

6) Vgl. die boek Widerstand und Ergebung. Briefe und Aufzeichnungen aus der Haft. Herausgegeben von Eberhard Betghe, Munchen 1970, S. 391-397.

7) Harvey E. Cox, The secular City. Secularization and Urbanization in theological perspective, London 1966, p. 265.

8) Vir nadere kennismaking met die teologie verwys ons slegs na Thomas J. J. Altizer en William Hamilton, Radical theology and the death of God, Indianapolis 1966. 
Die Niceense geloofsbelydenis spreek hom in geen onduidelike taal uit teen hierdie hele tendens in die Nuwe Teologie nie. Die God wat die Niceense geloofsbelydenis bely, is die almagtige Vader wat die Skepper van hemel en aarde en alle dinge, sienlike en onsienlike is. Hiermee word gestel dat niks in die ganse werklikheid buite die skeppingswerklikheid van God staan nie, maar dat $\mathrm{Hy}$ steeds as die Almagtige Vader homself as die lewende God wil openbaar deur vanuit sy verborge werklikheid in die hemel in te gryp in die lewe van mense (die Heidelbergse Kategismus Sondag IX). God bestuur die hele skepping, ook die hele mensewêreld so dat "alle skepsele so in sy hand is dat hulle sonder sy wil hulle nie kan roer of beweeg nie" (die Heidelbergse Kategismus vraag en antwoord 28). Nie net die sienlike werklikheid maar ook die onsienlike lê in God se hand. Daar is ook 'n werklikheid wat bo die mens uitgaan en wat vir die mens verborge en onbereikbaar is, en dit is die wêreld van die engele en geestelike magte, die wêreld van God se verhewe woning, die hemel. ${ }^{9}$ ) En daar vanuit die verborge en menslik onbereikbare werklikheid van God bereik God ons elke dag met sy liefde en Vadersorg.

Die Niceense geloofsbelydenis stel God in die middelpunt van die Godsleer. Die spreke oor God is nie 'n spreke oor die mens nie, maar oor God se openbaring in die mensewêreld.

\section{CHRISTUS}

\section{(i) Die Persoon van Christus}

Die tendens weg van die Goddelike na die menslike toe is ook baie duidelik in die uitsprake van die Nuwe Teologie oor die Persoon van Christus. ${ }^{10}$ ) Dit is baie duidelik dat Jesus met groot voorliefde slegs as 'n besondere mens gesien word, maar dat sy Godheid op die agtergrond bly of gestroop word van alle ware Godheid. So gaan Paul van Bure ${ }^{11}$ ) redelik uitgebreid in op die kerklike leerstelling van die twee nature van Christus. Hy het groot besware teen Griekse begrippe waarmee die saak uitgelê word. Vandag moet ons van ander begrippe gebruik maak as ons oor Jesus praat. Die aandag was vroeër vasgevang deur die feit van Christus se Godheid, dat Hy God was wat mens geword het. Vandag is dit anders, die klem verskuif

9) Otto Weber, Grundlagen der Dogmatik, Erster Band, Neukirchen-Vluyn $1964^{3}$, S. 536.

10) Die christologie van die Nuwe Teologie word deeglik behandel in die ongepubliseerde proefskrif van dr. J. H. Koekemoer ingehandig by die Universiteit van Pretoria: Die Christologie van die Nuwe Teologie in interpretasie probleem.

11) Sy hele boek The Secular meaning of the Gospel, London 1968, handel oor die christologie en moet a s geheel gelees word om sy volledige opvatting oor die christologie te verkry. 
na die waaragtige mens-wees van Christus - 'n mens gekenmerk deur sy aansteeklike vryheid. Van Buren se gedagtes oor die Persoon van Christus kan alleen só geinterpreteer word. So is dit met die Nuwe Teologie as geheel. Ons wil in opmerking van Sperna Weiland vryelik weergee $^{12}$ ) om die hele tendens in die Christologie weer te gee: Die belydenis dat Jesus die Seun van God, die Kurios, is word behou, maar met die voorbehoud dat dit niks anders is as 'n simbool nie wat weer opnuut uitgelê moet word en dan so dat ook hier in die Christologie afskeid geneem word van die metafisika, van die werklikheid van 'n Alhoë God. Die "vere homo", die waaragtige mensheid, kry 'n ongekende nadruk soos dit nog nooit in die kerkgeskiedenis gehad het nie. Dit is ook te verstane want die hele teologie draai om die mens.

(ii) Die werk van Christus

"The purpose of all Jesus said and did and hoped to do was always the social redemption of the entire life of the of the human race."13) Dit is nie vergesog om in hierdie woorde van Rauschenbusch een van die groot vaders van die "Social Gospel" 'n profetiese vooruitspieëling op die Nuwe Teologie se beskouinge oor die werk van Christus, te sien nie. Want die ganse opset van die Nuwe Teologie is so dat dit die werk van Jesus Christus reduseer tot die werk van 'n mens op die bloot menslike terrein. Die Goddelike element word heeltemal uit Jesus se werk gehaal en Christus se werk word uit en uit gebind aan bloot aardse, stoflike en menslike verhoudinge om nie weer daarbo uit te styg nie. Rauschenbusch ${ }^{14}$ ) was al van mening dat Jesus se werk nie anders as in sosiaal-ekonomiese terme geĩnterpreteer moet word nie en dat dit 'n fout is om in terme van die diens en aanbidding van die hoë en heilige God te dink. So is dit ook met die Nuwe Teologie van ons dag: Jesus se werk word verklaar in terme van menslike verhoudinge, politiese verhoudinge en aards-stoflike verhoudinge. Jesus se werk is beslis nie meer die van 'n Verlosser uit sonde en ellende nie, van 'n Versoener met God nie, van die Leidsman tot die ewige Lewe nie. Dit word beskou as onhoudbare metafisiese voorstellinge. Paul van Buren het so weggebreek van die tradisionele „metafisiese" begripsmateriaal wat maar net weer aan ' $n$

12) J. Sperna Weiland, a.w., blz. 178.

13) W. Rauschenbusch, Christianizing the Social Order, New York 1913².

14) L.c., p. 69 f.f., asook: Walter Rauschenbusch, Christianity and the Social Crisis, New York $1912^{15}$, p. 93 f.f. 
hoër werklikheid bind dat hy die hele christologie, dat hy alles wat Christus kom doen het, reduseer tot die vryheid, die vryheid wat Christus vir die mensheid geleef het. ${ }^{15}$ ) Dit is al waarin Jesus se werk lê. Soos Bultmann ${ }^{16}$ ) gesê het dat die verhale van die hemel en hellevaart van Christus "erledigt" is, so is die Goddelike heilswerk van Christus ook "erledigt" om maar net ' $n$ aardse heilswerk te wees. Carl Michalson ${ }^{17}$ ) sien Jesus se werk daarin dat $\mathrm{Hy}$ die Een is wat die "historicity" en die sinloosheid van ons bestaan oorwin. Harvey E. Cox ${ }^{18}$ ) beskryf die werk van Christus as die van die groot eksorsis, die duiweluitdrywer, wat die neuroses in die mens en die menslike samelewing oorwin. Christus word tot niks anders gemaak as 'n blote mens wat 'n suiwer menslike roeping kom vervul het nie, hoewel dan ' $n$ besonderse en uitnemende roeping, maar sy werk gaan nie verder as die bloot menslike nie.

Wanneer ons gaan kyk na wat die Niceense geloofsbelydenis hierteenoor van Christus bely dan is dit opvallend dat die leer van Christus se Persoon sterk op die voorgrond staan en dan veral die uitsprake oor sy Goddelike Natuur. Dit is so omdat die belydenis hom hier teen die dwalinge van die Ariane moes afgrens wat in hoofsaak die volgende dwalinge verkondig het: ${ }^{19}$ ) Daar is maar net een God, daarom sou Christus dan 'n mindere ondergeskikte, geskape godheid wees wat nog ten volle God, nog ten volle mens sou wees, maar ' $n$ mengwese. Omdat Christus slegs ' $n$ skepsel was, kon $\mathrm{Hy}$ dan ook geen Verlosser wees nie, want dit kan God alleen doen. Juis omdat Christus 'n skepsel was, kon Hy ook nie aanbid word nie, want dit sou dan afgodery wees.

Dit is van die dwalinge waarteen die Niceense geloofsbelydenis hom gerig het, maar hoe toepaslik is sy sterk bevestiging van die ware Godheid van Christus nie, in ons dag waarin sy Godheid afgetakel word. So sterk word die belydenis gestel dat die Niceense Vaders nie eers weggeskram het van die woord homoóusios nie - Christus is van dieselfde wese as die Vader. ${ }^{20}$ ) $\mathrm{Hy}$ is waaragtige God uit waaragtige God. Hierby het die belydenis net so 'n sterk belydenis van Christus se Goddelike heilswerk. Jesus

15) L.c.. p. 126 f.f.

16) R. Bultmann, Kerygma und Mythos I, Hamburg 1948, S. 17 f.

17) Carl Michalson, The rationality of faith. An historical critique of the theological reason, London 1964, p. 129-135.

18) L.c., p. 149-155.

18) Alan Richardson, Creads in the making. A short introduction to the history of christian doctrine. London $1969^{\circ}$, p. $52 \mathrm{f}$.

20) Otto Weber, A.a.O., S. 416 f.f 
se werk van verlossing uit die mag van die dood en versoening van die sonde word selfs beklemtoon met die woorde: „wat ter wille van ons mense en ons saligheid neergekom het uit die hemel".

Die Niceense geloofsbelydenis roep die mens van ons dag op om weer die Ware Christus in die middelpunt van ons geloofsdenke te plaas - Christus die waaragtige God wat ter wille van ons mense waaragtige mens geword het om so sy Goddelike heilswerk van verlossing en versoening te volbring.

\section{DIE HEILIGE GEES}

In die Nuwe Teologie vind ons nie so ver ons wete strek 'n uitgewerkte leer van die Heilige Gees nie. Die Heilige Gees word in groot mate op die agtergrond gestoot behalwe in die Nieu-Pentakolisme wat 'n beweging buite die gesigsveld van ons studie is. Hierdie skynbare belangeloosheid ten opsigte van die Persoon en werk van die Heilige Gees kan miskien verduidelik word deur te verwys na die Credo wat Dorothee Sölle voorgedra het by 'n byeenkoms in Keulen. ${ }^{21}$ ) Wat daarin van die Heilige Gees ter sprake kom is net die volgende:
„Ek glo in die Gees
wat met Jesus in die wêreld gekom het
in die gemeenskap van alle volke
en in ons verantwoordelikheid vir
wat van hierdie wêreld uiteindelik word
'n dal van ellende, honger geweld
of die stad van God."

Die Heilige Gees is slegs 'n verskoning om tot die wêreld, tot die gemeenskap van alle volkere, tot aards-stoflike behoeftes oor te gaan. Die wêreld, die mens het al die aandag. Die Nuwe Teologie sal beswaarlik daartoe kan kom om oor God se werk in die mens - die werk van die Heilige Gees - te praat as dit nie meer wil praat oor God se werk aan die mens - sy heilswerk in Christus nie. Die Niceense geloofsbelydenis roep ons uit ons mensbeheptheid en ons beheptheid met ons eiebelange en werke tot die werk van God se Gees in ons - die Gees wat van die Vader en die Seun uitgaan om as Lewendmaker en Heer in ons lewe te staan. Ons kan God nie uit ons lewe ban nie, Hy wil as Heer en Lewendmaker deur die Heilige Gees in ons woon.

21) Dorothee Sölle en Fulbert Steffensky, Politiek avondgebed, Baarn 1969, p. 24 en 25. 
Dit is lankal geen onbekende feit meer dat daar in baie kerklike kringe van ons dag 'n gedagtestruktuur en denkpatroon gevind word wat groot formele ooreenkomste toon met die MarxismeLeninisme. ${ }^{22}$ ) Die ooreenkoms lê in die materialisme wat die filosofiese grondslag van die Marxisme-Leninisme ten grondslag lê - 'n gedagterigting wat alles reduseer tot stoflike verskynsels, werkinge van stof en krag. Hoe hierdie formele ooreenkomste nou ook al verklaar moet word, baie kerklike kringe het in 'n sterk materialistiese denkpatroon verval waarin alles net draai om stoflike verhoudinge. En nêrens anders kom hierdie denkpatroon duideliker uit as by hulle siening van wat die kerk is. Ook wat die wese en doel van die kerk betref, vind daar in die kringe ' $n$ verskuiwing van God na die mens toe plaas. Die kerk is nie meer die liggaam van Christus nie, maar die dienaar van die mensheid na die stoflike. Die taak van die kerk sou net wees om stoflike verhoudinge reg te stel. Die kerk het nie meer ' $n$ Goddelike oorsprong en roeping nie, maar het slegs ' $n$ menslike, 'n sosiaal-aardse taak en roeping. Rauschenbusch ${ }^{23}$ ) het alreeds van die Bybelse boodskap wat die kerk moet uitvoer gesê: "the kingdom of God was a social and collective hope and it was for this earth." Die kerk het slegs 'n aards-menslike taak, daarom kan Gibson Winter ${ }^{24}$ ) dan ook onbeskaamd van ons roeping in die wêreld sê dat dit is dat mense geroep word om hulle verantwoordelikheid vir die toekoms van die mense op hulle te neem en om dit uit te leef, saam te leef, onbeskut in die geskiedenis wat dan 'n sekulêre menslike taak is. Hierdie taak is sekulêr, dit wil sê dit is sonder God, dit is menslik, dit is ' $n$ verantwoordelikheid alleen vir die aardse toekoms van die mens.

Cox ${ }^{25}$ ) sien die taak van die kerk ook op suiwer menslike en aardsgebonde vlak. Hy is van mening dat die kerk se taak daarin lê dat die kerk in die wêreld moet optree as eksorsis (duiweluitdrywer). Aangesien die geloof in demone nie meer bestaan nie, lê die eksorsisme in die bestryding en ontmaskering van die magte in ons samelewing wat die mens se lewe bedreig

22) B. J. Engelbrecht sit die saak duidelik uiteen in sy artikels oor die kommunisme en die godsdiens en wel in: Die kommunstiese aanslag op die kerk in die publikasie: Christendom teen Kommunisme. Referate gelewer by die volkskongres oor kommunisme, Potchefstroom 1964, bls. 24-55. verder: Die kommunisme en die Godsdiens in die publikasie: Kormmunisme: Teorie en Praktyk onder redaksie van prof. G. Cronjé en laastens: Hedendaagse Krisispunte in die Teologie in Hervormde Teologiese Studies, Jrg. 23, Af. I, bls. 5-23.

23) Christianizing the Social Order, p. 76.

24) Gibson Winter, The new creation as metropolis. New York 19653, p. 68-86.

25) L.c., p. 149-166 veral p. 154. 
en hom die moontlikheid van sy menswees ontneem. Op in later stadium skryf hy in die voorwoord van 'n nuwe boek ${ }^{26}$ ) dat hy intussen 'n verandering ondergaan het wat hom in die buurt van die "New Left" beweging bring. Hy het ingesien dat die taak van die Christene verander het. Hulle taak is nie alleen om in 'n veranderde maatskappy die rol van eksorsis op hulle te neem nie, maar om veranderinge aan die gang te sit en aan te moedig ook waar dit nie gewil word nie.

In die denkrigting het die taak van die kerk so gehumaniseerd geword, dat daar niks anders as die mens en sy ideale oorgebly het nie en die logiese uitvloeisel is dat die kerk dan ook die dienskneg van menslike ideologië en sisteme moet word. Dit lyk nie onwaarskynlik dat daar in die uiteinde van die ontwikkeling van die humanistiese ekklesiologie van die Nuwe Teologie in die plek van die kerk net maar die politiek-revolusionêre strewe na menslike paradys op aarde oorbly soos verwoord in die Credo van Sölle:27)

elke dag het ek opnuut angs

dat hy (dit is Christus - D.J.S.) verniet gesterf het

omdat ons hom in ons kerke begrawe het

omdat ons sy revolusie versaak het

in gehoorsaamheid aan en in angs vir die outoriteite.

Die gevolg van hierdie hele ontwikkeling is dan dat ons vandag teologieë kry wat geheel en al gebou is om menslike vryheid. menslike regte, die gemeenskaplike menslike toekoms, die revolusionêre verandering van die maatskappy tot voordeel van die verdrukte mens - en dit alles sou die enigste taak van die kerk wees. In die opsig dink ons byvoorbeeld aan die teologie van die revolusie waarvan Richard Shaull een van die vaders $i^{28}$ ) en ook aan die sogenaamde Swart Teologie soos dit deur Cone uiteengesit word. ${ }^{29}$ ) Hier het die kerk verander van die liggaam van Christus wat die dienswerk van Christus in die wêreld moet doen. tot die liggaam van die mensheid wat die dienswerk van die mens moet doen.

Hierteenoor tely die Niceense geloofsbelydenis die een heilige, algemene en apostoliese kerk. Die kerk is een omdat dit die eiendom van die een Heer is en deur sy een Woord gelei word. Die kerk is heilig omdat dit deur God geheilig is, deur die heilswerk van Christus aan die diens van God toegewy is. Die kerk is apostolies omdat dit vashou aan die prediking van die apostels wat die kerk oproep tot die diens van God en Christus. Die kerk is "van die Here" omdat dit die liggaam van Christus is.

26) Harvey E. Cox, Feast of Fools. A theological essay on festivity and fantasy. Boston 1969.

27) a.w., blz. 24 v.

28) Sy standipunt kom mooi na vore in die boek: R. Shaull: Uitdaging aan kerk en maatschappy. Verandering - vernieuwing - bevrijding, Baarn 1969.

29) James H. Cone, Zwarte Theologie en Black Power, Roermond 1970. 
In die eskatologiese uitsprake van die Nuwe Teologie is hierdie swaai van God en sy werklikheid af na die mens en sy wêreld toe, baie opvallend. Dit is so dat daar by baie teoloë nie meer plek is vir 'n toekoms van God wat nie van hierdie wêreld is nie, maar dat alle verwagtinge vir 'n toekoms alleen op hierdie mensewêreld as die enigste gerig word. Al die aandag word dan ook op hierdie mensewêreld as die enigste werklikheid gerig en alle gedagtes aan ' $n$ hiernamaals as denkbeeldig afgewys. ${ }^{30}$ ) Die opset van die Nuwe Teologie is so dat die mense of geen plek vir 'n eskatologie, 'n leer van die toekomsverwagting, het nie, of die eskatologie word so verklaar dat dit 'n verwagting van hierdie wêreld is en uit die mense self voortkom - ' $n$ verwagting waarin elke transendente werklikheid soos hemel, hel ens. nie aanvaar kan word nie. So wys Bultmann ${ }^{31}$ ) so ' $n$ verwagting af omdat dit nie te rym is met die wetenskaplik ervaarbare en verifieërbare werklikheid soos uitgedruk in die wêreldbeeld van die moderne mens nie, en hy dan bygevolg sake soos hemel en hel wil interpreteer in terme van die wêreldbeeld van die moderne mens.

Die Nuwe Teologie is van mening dat ' $n$ hemelse verwagting geen plek meer het in ' $n$ gesekulariseerde samelewing nie, al wat oorbly is die lewe volgens die lewensstyl van die profanity van Cox - die lewe binne ' $n$ aardse horison sonder ' $n$ bo-aardse werklikheid wat hom aan ons opdring. ${ }^{32}$ ) Michalson is van mening dat die Christelike geloof slegs geleef word in die aardse geskiedenis en verantwoordelikheid vir wat van die aardse geskiedenis word ${ }^{33}$ ) en die toekomsgerigtheid, die eskatologiese van die Christelike geloof verklaar hy dan so dat dit alleen 'n toekomsverwagting van hierdie wêreld is. ${ }^{34}$ ) In hierdie gedagtes van hom sluit hy baie nou aan hy Bonnhoeffer wat o.a. sê dat ons nie opgeroep word tot 'n vreemde burgerskap daarginds in die hiernamaals nie, maar tot 'n koninkryk van geregtigheid op hierdie aarde, waarin alles op hierdie aarde gerig is en niks bo hierdie wêreld uitgaan nie. ${ }^{35}$ )

Die Nuwe Teologie het God en die hoëre werklikheid van God uit sy toekomsverwagting gehaal en moes iets anders in die plek van God, die hemel, die ewige lewe ens. stel. En die ontwikkeling was dan so dat die plaasvervanger vir God en die verwagting van die toekoms by God, slegs die mens, die

so) Carl Michalson, I.c., p. 130-135.

31) Jesus Christus und die Mythologie, S. 18.

32) The secular City, p. 60.

33) I.c., p. 131 en 138.

34) I.c., p. 129 f. en 137

35) A.a.O., S. 312 . 
medemenslikheid, die diens van die mens en die besorgdheid oor die toekoms van die mensheid is. Die eensydige mensgerigtheid van hulle toekomsverwagting moes dan ook onvermydelik oorgaan in 'n politieke betrokkenheid vir die uitbouing van en verantwoordelikheid vir die toekoms van die aardsgebonde mens. Die heil vir die toekoms word gesoek in ' $n$ politieke idee. Daarom sê Cox dat ons spreke oor God 'n ,political issue" is. ${ }^{36}$ ) Die toekoms sal polities bepaal word. Wat kan ons meer hierteenoor sê as die Nicerum: ons verwag die opstanding van die dode en die lewe van die toekomstige eeu. Amen.

\section{GEVOLGTREKKINGS}

Die groot swaai in die teologiese opset behoort uit hierdie sketsmatige oorsig duidelik te wees. Die ganse teologie is algaande gestroop van alles wat God en sy werklikheid raak. Die gesigsveld van die teologie van die Nuwe Teologie het so ingekrimp dat dit nog God, nog sy werk, nog sy werklikheid, nog sy openbaring, nog sy toekoms meer in sig hou. Al sodanige verwysings word as metafisies beskou en daarom ook as ongeldig. Die teologie het net een fokuspunt - en dan word al sy belangstelling, sy hele gesigsveld op die punt gerig en dit is die mens met sy aards empiriese wêreld. Die fokus op die mens met sy histories-empiriese wêreld is so sterk dat ons hier met ' $n$ humanistiese teologie in ' $n$ heeltemal nuwe $\sin$ van die woord te doen het. Hier het ons met ' $n$ volledig gehumaniseerde teologie te doen, want waar die ou humanistiese teologie nog vanuit God die oordrewe aandag op die mens gevestig het, rig hierdie gehumaniseerde teologie vanuit die mens die aandag op die mens sonder dat God ter sprake kom. Hier het ons 'n volledige Mens-teologie.

In die lig hiervan het die Niceense geloofsbelydenis 'n duidelike en belangrike boodskap aan die kerk van ons eeu. In die eerste plek roep dit ons op tot die lewende God en om te erken dat hierdie werklikheid in sy hand lê. Die .,God is dood"-teologie wil God sy plek in ons wêreld ontneem; hulle wil God van sy werklikheid van sy bestaan, van sy teenwoordigheid in sy skepping ontneem. Die kerk sal daarom moet stry vir die werklikheid van God self. Met die Niceense geloofsbelydenis kan die kerk dan ook doen waartoe B. J. Engelbrecht oproep: „Die kerk sal moet bely en verkondig dat dit resloos vashou aan die objektiewe realiteit van die enige God van die Bybel,

36) The secular City, p. 249-257. 
aar sy openbaring en aan sy wêreld soos byvoorbeeld die hiernamaals en die ewige lewe." ${ }^{\prime 3}$ )

In die Nuwe Teologie het dit baie duidelik geword dat die hele yang en opset van die teologie deur die christologie bepaal word. Word Christus sy Godheid en sy Goddelike werk ontneem, dan bly daar in die ganse teologie niks anders as die mense-wêreld en mensewerk oor nie. Dan verdwyn die hele wêreld van God wat geopen word deur die Goddelike verlossing en versoening van Christus, want dan bly daar geen verlossing en versoening meer oor nie. Die hele opset van die teologie word bepaal deur die opset waarin die christologie gegiet is. In die lig hiervan is dit te verstane waarom dit in ons tyd weer nodig is om 'n diepgaande studie te maak van wat die Niceense geloofsbelydenis werklik aangaande Christus wil bely en om die ou waarheid opnuut te bely. Alan Richardson ${ }^{38}$ ) sê dan ook tereg: ,When we have perceived that the principle enshrined in the Chalcedonian Definition or the Nicene Creed is the principle for which the NEW Testament writers pleaded - that in the man Jesus Christus we may see the Incarnation of God - we will realise that we are also confronted with the same question which the ancients faced and answered; and at least we shall not let that question go unanswered because we have not grasped what it is. We shall then be able honestly to face the question, 'What think ye of Christ?' and shall be able to answer it because we have considered both the answers which historical Christianity has given and also the answers which have been rejected."

Die Pneumatologie kan nie ter sprake kom sonder dat ons gedwing word om uitspraak te gee oor Jesus se belofte voor sy hemelvaart dat $\mathrm{Hy}$ tot aan die einde van die dae met die gelowiges sal wees nie, want hierdie belofte is vervul in die koms van die Heilige Gees. So stel die waarheid wat die Niceense Geloofsbelydenis aangaande die Heilige Gees bely, die Nuwe Teologie voor die vraag of hulle werklik glo dat God uit die wêreld afwesig is en of God nie onweerlegbaar in die wêreld is as die Heer en Lewendmaker, die Gees van die Vader en die Seun nie.

Die kerk van ons dag het 'n groot roeping ten opsigte van die ekklesiologie. Dit is by die leer van die Nuwe Teologie oor die kerk baie duidelik dat wanneer die oorsprong en wese van die kerk suiwer menslik gesien word, dan kan die roeping en taak. van die kerk ook nie ancers as bloot menslik, aards, sosiaal,

37) B. J. Engelbrecht, Die antwoord en tak van die kerk ten opsigte van Sekularisasie in: Hervormde Teologiese Studies, Jaargang 24, Afl. 3, bls. $153 \mathrm{v}$.

38) I.c., p. 86 f. 
polities en ideologies gesien word nie. In die opsig kan die kerk geen geleentheid laat verbygaan om na die gees en die bedoeling van die Niceense geloofsbelydenis die Goddelike oorsprong en wese van die kerk en daarom ook die Goddelike roeping en taak as liggaam van Christus te bely nie.

Die Nuwe Teologie beperk die mens se hele toekomsverwagting tot hierdie aarde. So is daar geen ander verwagting vir die mens as om maar net êrens in hierdie wêreld in ideale stoflike omstandighede tereg te kom of in ' $n$ ideale medemenslike gemeenskap. Die mens het sy eindbestemming by God en Christus verloor. Die tyd is ryp om met die Niceense geloofsbelydenis ons hemelse toekomsverwagting te bely want so sê ons aan die mens van ons dag dat die mens se eintlike bestemming by God en Christus is, in die beter hemelse vaderland (Hebr. 11:16) waar ons burgerskap is (Fil. 3:20).

Hierdie belydenis van die eindverwagting is ook om nog ' $n$ ander rede nodig want Calvyn het nie al verniet gewaarsku dat ons die allerellendigste van mense sal wees indien ons nie ons deur ons hart in die hemel te verhef, alles oorwin wat in die wêreld is nie. ${ }^{39}$ )

Van Rensburg stel dit so: „Wie die eskatologiese perspektief prysgee, wie hierdie transendente einddoel laat vaar, verval in 'n moralistiese vervlakking of troostelose pessimisme, want hy gee die hoop en troos van die Christelike geloof prys, en soek op sy beste die koninkryk wat van hierdie wêreld is. Hy laat die transendente werklikheid waarop die christelike hoop (elpis) sig rig, los en vergenoeg sig met 'n koninryk van "diesseitige" menslike doeleindes". ${ }^{40}$ ) Saam met die Nicenum wil ons in die wêreld ons verwagting van die lewe van die toekomstige eeu bely want dit is ' $n$ verwagting en einddoel wat bo elke aardse verwagting en einddoel uitgaan.

39) Calvyn, Institusie, III, IX, 6. (Vgl. I Kor. 15:19).

40) S. P. J. J. van Rensburg, Die sin van die Nieu-Testamentiese eskatologie, in Hervormde Teologiese Studies, Jaargang 23, Afl. 4, bls. 119. 